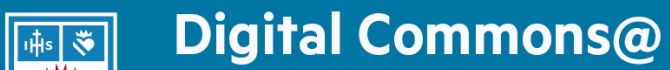

Loyola Marymount University

LMU Loyola Law School

\section{Journal of Catholic Education}

6-1-1998

\section{Private Schools: Partners in American Education - Overview and Directions for Further Research}

Thomas C. Hunt

Joseph M. O’Keefe

Follow this and additional works at: https://digitalcommons.Imu.edu/ce

\section{Recommended Citation}

Hunt, T. C., \& O'Keefe, J. M. (1998). Private Schools: Partners in American Education - Overview and Directions for Further Research. Journal of Catholic Education, 1 (4). http://dx.doi.org/10.15365/ joce.0104102013

This Review of Research is brought to you for free with open access by the School of Education at Digital Commons at Loyola Marymount University and Loyola Law School. It has been accepted for publication in Journal of Catholic Education by the journal's editorial board and has been published on the web by an authorized administrator of Digital Commons at Loyola Marymount University and Loyola Law School. For more information about Digital Commons, please contact digitalcommons@lmu.edu. To contact the editorial board of Journal of Catholic Education, please email JCE@nd.edu. 


\title{
PRIVATE SCHOOLS: PARTNERS IN AMERICAN EDUCATION-OVERVIEW AND DIRECTIONS FOR FURTHER RESEARCH
}

\author{
THOMAS C. HUNT \\ University of Dayton \\ JOSEPH M. O'KEEFE, S.J. \\ Boston College
}

ccording to the most recent statistics available from the federal govern-
ment (McLaughlin \& Broughman, 1997), there are 26,093 private elementary and secondary schools in the United States. $24.4 \%$ of all schools. Of these. $38 \%$ have no religious affiliation, $32 \%$ are affiliated with the Catholic Church, $18 \%$ are labeled Conservative Christian, and $13 \%$ are associated with other religious denominations. Private schools serve $10.7 \%$ of the nation's school-aged children. The schools tend to be smaller than their public counterparts, and they differ significantly in administrative structure, curriculum, and ethos. While one could claim that their strength lies in their autonomy, they have much to learn from one another. To that end, Thomas Hunt brought together a nationwide group of educators in an attempt to develop a coherent research vision for these institutions.

The conference, entitled "Private Schools: Partners in American Education," took place at the University of Dayton, November 5-7, 1997. This review highlights the research suggestions and questions that emerged from the addresses, responses, and breakout discussion groups. The conference had three overarching themes:

- The Identity and Value of Private Education

- The Financial, Legal, and Political Context of Private Education

- Internal Issues in Private Education 
The conference planning group provided stimulus questions for each theme, and each set of questions was addressed by a major speaker and a group of respondents: Rabbi Michael Paley on identity and values with responses from Ann Hicks and Fr. Joseph $\mathrm{O}^{\circ}$ Keefe. SJ; Bruno Manno on the financial, legal, and political context with responses by Bruce Cooper, Lyndon Furst, and Charles Russo; and Sr. Lourdes Sheehan, RSM, on internal issues with responses by John Holmes and Sr. Mary Peter Traviss, OP. After each of the three sessions, participants engaged in discussion groups to raise questions and offer insights. There were also two keynote speakers: Fr. James Heft. SM, and Charles Glenn. Stephen Broughman was the luncheon speaker. Five people were designated as wrap-up speakers: James Carper, Sr. Dale McDonald. PBVM, Carolyn Benz, E. Vance Randall, and Theodore J. Wallace.

Below are selected questions raised in the discussion groups which followed the major presentations and responses.

\section{THEME ONE-IDENTITY AND VALUE OF PRIVATE EDUCATION}

- How is religion positioned in the curriculum?

- What effect does the integration of religion within the curriculum have on students?

- To what degree is school practice congruent with stated values?

- What effect does religious diversity have on school identity and sense of community?

- Are there values commonly shared among private schools? Private religious schools?

- Do the value orientations of private schools contribute to the development of a healthy school climate?

\section{THEME TWO-THE FINANCIAL, LEGAL, AND POLITICAL CONTEXT OF PRIVATE EDUCATION}

- What effects do funding options have on the mission and identity of private schools?

- What choices are currently available for the poor?

- What would private religious schools not be willing to give up in order to receive public funding?

- What should a comprehensive evaluation of a private school look like?

- What impact do accrediting bodies and professional organizations have on the identity of private schools? 
- In addition to raising questions, the participants agreed upon the need for regular dissemination of updates of court decisions impacting private schools.

\section{THEME THREE-INTERNAL ISSUES IN PRIVATE EDUCATION}

- How can higher educational institutions effectively strengthen the private school movement?

- What percentage of elementary private school students persist in private education?

- What constitutes a "critical mass" of minority students in a school?

- What programs are available in private schools for gifted and special needs students?

-What strategies are effective for helping new teachers promote the schools' mission?

- Do private school teachers have the resources and time for professional development and collaborative teaching?

- What curriculum innovations and initiatives are being tried in private schools?

- What governance models are currently being used in private schools?

- When a large number of students and staff do not share the sponsoring group's values, what is the impact on a private school?

\section{WRAP-UP PRESENTATIONS}

The five wrap-up speakers summarized the research questions identified throughout the conference. They likewise articulated thematic issues that could form the basis for a private education research vision.

Carolyn Benz, the first presenter, suggested that for religiously affiliated private schools the dialogue between faith and culture should be a line of inquiry for the future. Picking up on the challenge offered by one speaker that we not diminish our efforts to infuse spiritual values in religious schools and that we push to commit to the betterment of society, Dr. Benz contended that we were inextricably tied to both public institutions and religious life. She asked, "How can we combine academic subject matter and religious thought while making both richer and more meaningful?" She further queried: What are the values, the faith experiences, of those students in public schools who maintain their religious beliefs?

James Carper noted that several major research questions were missed, even though a wide range of researchable topics were identified at the conference. Pointing to the scant media coverage of the conference, he maintained that we need to examine how the media portrays private schools - in 
the past and present. He felt that attention to "less visible" members of the private school universe, such as African American Christian and Muslim schools - their ethos, clienteles, and nonacademic outcomes - might tell us much about school effectiveness and parental involvement. He called for research on the mindset of state legislators toward nonpublic schools which. he believed. would be of considerable help to private school policy makers. Dr. Carper supported those in the conference who had called for the utilization of qualitative research, which would help us know the "soul" of the nonpublic school. In conclusion. he urged that all heed the admonition-that we stand for something, alleging that the greatest threat to private schools was not external but internal. The greatest risk is a loss of vision or narrative: "Where there is no vision, the people perish" (Proverbs 29:18).

Sr. Dale McDonald outlined her ideas under four headings. Under the first heading. "Where Do We Go From Here?" she examined notions of public and private as they relate to education. She argued that we need to research and answer several questions: How does society define the concepts public and private? What constitutes the public and private nature of institutions labeled as private schools. and what kinds of data are necessary to develop and refine these concepts"? Under the category "Finding Common Ground for Private Education" she asked. How do various groups define their self-interest in their educational mission? How do these different groups understand the common good? From a public policy perspective, what are the commonalties and differences in mindset within the private school community? What is the potential of these differences for promoting divisiveness?

Her third heading was "Threats and Opportunities Inherent in the School Choice Movement." She called attention to how this movement should be supported ideologically, politically, and financially. Questions for examination should include: How can and should the private school community support a range of choice options on the part of parents when such choice might adversely impact other schools? What are the unintended consequences of school choice regarding questions of equity, opportunity. and ethics? How can the private school community avoid the perception or reality of using the poor and minorities as laboratory experiments in choice and voucher wars? And as charter schools begin to blur distinctions between public and private. what might the conversion of some religious schools to charter status be? McDonald's fourth category was entitled the "Need to Research the Research." She articulated the need to enhance and coordinate various databanks of available research on private education and make them user-friendly: to produce a compendium of completed research and commission new research: to conduct a meta-analysis of the growing body of private school research that is being done on school choice, school effects, comparison between public and private education. etc.: and to ensure the integrity of the 
research by developing a core of independent researchers who were interested in private schooling and did not have a personal or ideological stake in the findings.

Bruce S. Cooper collaborated with E. Vance Randall in developing the fourth wrap-up presentation, delivered by Randall. They identified eight major research strands or agendas:

1. Marketing Private Schools. How can private school researchers conduct a demographic analysis, project needs and demand, and ascertain the reasons why parents choose nonpublic schools?

2. Teacher and Administrator Development. What is the process of identifying. preparing, and supporting teachers and administrators in nonpublic schools in light of the schools' mission? What is the impact of lay governance and predominately lay staff on the spiritual ethos and core mission of the school?

3. Standards, Assessment, and Accreditation. What are the standards, how are they set and by whom, and how are these standards measured or assessed? In what ways do these standards relate to accreditation by the state, regional accrediting bodies, and faith community groups?

4. Institutional Values. What are the core values of private schools? Using a variety of research methods, how can one evaluate the extent to which these values are encoded and integrated into the educational practice in these schools? Do schools "walk the talk"?

5. Finance and Development. What are the sources of revenue, both public and private, available to private schools? What development strategies are employed by private schools? How can private schools take advantage of financial resources, other than tuition, while still preserving their unique mission and identity?

6. Building Bridges. How do schools within the same faith community build relationships with each other, across faith communities, with public schools and quasi-schools? How are the public choice initiatives, such as magnet schools and charter schools affecting private schools?

7. Diversity. What is the degree of racial, socioeconomic, ethnic, and religious diversity among students, teachers, and administrators in nonpublic schools? What can be done to increase the diverse character of the student body and staff in private schools?

8. Effective Schools. What are the criteria of effectiveness for private schools? How are these standards of effectiveness determined and by whom? How can school effectiveness, both intellectual and affective, be measured and evaluated in public and private schools?

In conclusion, Randall suggested five ways to continue the work of the conference: identify research needs and create multiple research agendas; determine who will conduct the research in collaboration with others to support the research: locate resources, both human and fiscal, to carry out this research; build organizational structures between and within nonpublic 
school assuciations to coordinate and carry out the research agenda: and clarify the role of the university research community, noting that $80 \%$ of all research in education is done by doctoral students.

Theodore J. Wallace referred to John Convey's Catholic Schools Make a Difference: Tw'enty-five Years of Research (1992). He called for a similar volume about all private schools and for a companion work on dissertations focusing on private schools. This would provide clarity and appreciation of what has been done and direction on what needs to be researched more thoroughly. In order to disseminate findings about private schools, he suggested the creation of an e-mail list serve network so that members of the private school community can conduct regular inexpensive conversations and not lose the momentum gained from this national conference.

\section{REFERENCES}

Convey, J. (1992). Catholic schonls make a difference: Twenty-five years of research. Washington, DC: National Catholic Educational Association.

McLaughlin. D. H.. \& Broughman, S. (1997). Private schools in the United States: A statistical profile, 1993-1994. Washington. DC: United States Department of Education, National Cinter for Education Statistics.

Thomas C. Hum is a professor at the Center fur Catholic Educution in the University of Daytuns School of Education. Joseph O'Ke'efe, S.J., is an associute professor in the School of Educution at Boston College.

To obtain copie's of the proceedings of "Private Schools: Partmers in American Educution." sind \$30 per copy "o:

Peter Li Education Group, PSC

33) Progress Road

Dayton, $\mathrm{OH}+5+49$ 
Copyright of Catholic Education: A Journal of Inquiry \& Practice is the property of Catholic Education: A Journal of Inquiry \& Practice and its content may not be copied or emailed to multiple sites or posted to a listserv without the copyright holder's express written permission. However, users may print, download, or email articles for individual use. 